\title{
Unresolved Jurisprudence of Crime against Humanity under Article 7 of the Rome Statute of the International Criminal Court
}

\author{
Moruf O. Mimiko', Olaposi A. Olaseeni², Akin Olawale Oluwadayisi' ${ }^{1}$ \\ ${ }^{1}$ Faculty of Law, Adekunle Ajasin University, Akungba-Akoko, Nigeria \\ ${ }^{2}$ Faculty of Law, Obafemi Awolowo University, Ile-Ife, Nigeria \\ Email:kaymimiko@gmail.com,kaymimiko@yahoo.com, oaolaseeni@yahoo.com
}

How to cite this paper: Mimiko, M. O., Olaseeni, O. A., \& Oluwadayisi, A. O. (2016). Unresolved Jurisprudence of Crime against Humanity under Article 7 of the Rome Statute of the International Criminal Court. Beijing Law Review, 7, 420-429.

http://dx.doi.org/10.4236/blr.2016.74033

Received: September 1, 2016

Accepted: December 27, 2016

Published: December 30, 2016

Copyright $\odot 2016$ by authors and Scientific Research Publishing Inc. This work is licensed under the Creative Commons Attribution International License (CC BY 4.0).

http://creativecommons.org/licenses/by/4.0/

\begin{abstract}
Crime against humanity is one of international crimes. The "validity" of this crime as a criminal offence under International Criminal law can be traced to the Rome Statute, which by virtue of Article 7, makes it an offence. The International Criminal Court (ICC) is a court saddled with the responsibility of interpreting and also bringing to book those who have violated international criminal laws. The paper therefore examines how the broad couching of article 7 has brought complexity into the jurisprudence of "crime against humanity" and how it has created interpretation problems; not only to the court, but to victims and accused persons. A good law must be concise, precise and must not be too broad. This article, therefore, argues that an appraisal of Article 7 will go a long way in clarifying the ambiguity created by this article.
\end{abstract}

\section{Keywords}

Crime against Humanity, Systematic, Widespread, Civilian, Organizational and Policy

\section{Introduction}

The concept of "crime against humanity" is as old as humanity (Theodorakis \& Farrington, 2013). The concept became a buzzword during and after the massacre of the Armenians by the Ottoman Empire and other massacres committed in World War I (Dadrian, 1989). Article 7 of the Rome Statute of the International Criminal Court explains that the concept of crime against humanity includes "wide spread or systematic attack directed against civilian population, with the knowledge of the attack": Antonio (2002). While the list of crime against humanity is not limited to the above, it is apt to mention that Article 6(c) of the Nuremberg Charter played a significant role in influ- 
encing the tenor of Article 7 of the Rome Statute, which is in all fours with Article 6(c|) of the Nuremberg Charter (Mauro \& Giuseppe, 2001) ${ }^{1}$. In other words, it can be argued that Article 6(c) of the Nuremberg Charter laid the foundation for the birth of Article 7 of the Rome Statute.

In order to do an anatomic analysis of Article 7, we shall first of all have a brief background knowledge of the Rome Statute and the International Criminal Court before examining the jurisprudence of the wordings of the Article 7 with regard to the following keywords, vis-à-vis, "systematic", "knowledge of the attack", "wide spread”, “civilian", “organization", and "policy requirement". These would solidify the claim that the broad couching of Article 7 has plagued its meaning with coherence unlike the clarity in the definition of genocide and war crimes. It is sad to note that years after the adoption of the concept of crime against humanity, its interpretation is still not clear, thereby making the concept less of a value (Diane, 1991) ${ }^{2}$. The paper therefore examines article 7 of the Rome Statute and thus argue that the re-appraisal of the Article would go a long way in providing a clearer interpretation and definition of crime against humanity.

\section{The Jurisdiction of the International Criminal Court}

The Roman Treaty of 17 July 1998, establishing the International Criminal Court, is the most significant accomplishment in international legal order post 1945 era (Otto, 1999). The history of the Statutes dates back to 1998, but the Court became a court of jurisdiction in July 2002, upon ratification by 60 states $^{3}$. The Court's official seat is in Hague, Netherlands, but its proceedings may be delegated to take place anywhere. Cases are referred to the ICC (as this acronym is used here) through "a referral of a situation by a state party", by the Security Council or by the "Prosecutor" (Cassese, 2002). The Court can only try cases that are within the jurisdiction of the Rome Statute (Broomhall, 2003).

The jurisdiction of the International Criminal Court covers: Crime against humanity, war crimes, genocide, and the crime of aggression which is yet to be added into the Statute due to "definitional problems" (Ebrucoban, 2014). The Court may exercise jurisdiction over individuals who have violated the provisions of the Statute, and tends to go after the $B I G-G U N S$ because of the difficulties involved in prosecuting all those who partook in the commission of the crime as a result of the magnanimity of the number of people involved and the huge resources involved in bringing to book the perpetrators

${ }^{1}$ Charter of the International Military Tribunal (1945). Available online on: http://law2.umkc.edu/faculty/projects/ftrials/nuremberg/nurembergindictments.html. [Accessed 7th December, 2016]. See also, Mauro \& Giuseppe (2001). “The Rome Statute of the International Criminal Court. A Challenge to Impunity”. Burlington, Ashgate, p. 76.

${ }^{2}$ Diane (1991) "Settling Accounts: The Duty to Prosecute Human Rights Violations of a Prior Regime", 100 (8). Yale Law Journal. pp. 2567-2690, p. 2587. See also, "The Convention on the Prevention and Punishment of the Crime of Genocide", (1948) Dec 9, 78 U.N.T.S. 277 (entered into force Jan. 12, 1951).

${ }^{3}$ Mark (2006) "Knowledge-Transfer, Legal Empowerment, Capacity, Building”. Available on: https://www.casematrixnetwork.org/cmn-knowledge-hub/icc-commentary-clicc/commentary-rome-statute/c ommentary-rome-statute-part-2-articles-11-21/ [Accessed 10th November, 2016]. 
of these heinous crimes.

\section{The Principle of "Complementarity" under the Rome Statute}

The provision under Article 17 of the Rome Statute gave the States the power to prose-

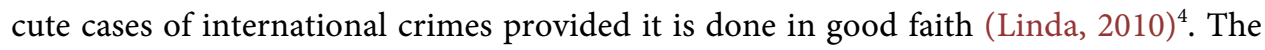
idea behind this principle is that, it is presumed that cases of crimes committed in each state should be dealt with by the state, since the municipal law would have made such acts an offence. The jurisdiction of the International Criminal Court is thus supplementary to domestic Courts and it is not to be exercised where those Courts are functioning properly. The idea behind the principle of "complementarity" is that the International Criminal Court wants to complement existing judicial system of the States.

\section{The Jurisprudence of Crime against Humanity under the Rome Statute}

The lack of clarity in the wordings of Article 7 has not helped in the development of the jurisprudence of crime against humanity. For the purpose of this paper, Article 7(1), and $7(2 a)$ of the Rome Statute will be examined respectively to elicit the jurisprudential value of this discourse. They provide as follows:

7(1) For the purpose of the statute, "crime against humanity" means any of the following acts when committed as part of widespread or systematic attack directed against any civilian population, with knowledge of the attack ... ${ }^{5}$

2. For the purpose of paragraph 1:

(a) Attack directed against any civilian population means a course of conduct involving the multiple commission of acts referred to in paragraph 1 against any civilian population, pursuant to or in furtherance of a State or organizational policy to commit such attack,...

For a crime to be termed as "crime against humanity", it must have been committed "systematically" and must have had a "wide spread" effect. Under Article 7(1), the $A c$ tus Reus (the physical act) must be of large scale, and the Mens Rea (the mental element) of the attacker as seen in paragraph 2 must have been "... directed against any civilian population, with the knowledge of the attack...". "Knowledge of the attack" here is that the attacker must have known and played a significant role in the physical attack carried out on the civilian. It is until then, that is, when the aforethought knowledge of the crime is followed by the physical act of the crime, that the accused can be liable under Article 7 of the Rome Statute.

\section{The Jurisprudential Problem with "Systematic"}

"Systematic" is defined as "done or acting according to a fixed plan or system" (Soanes

${ }^{4}$ Linda (2010) "The Principle of Complementarity and International Criminal Court: The Role Of Ne Bis, in Idem 8 (1) Santa Clara Law Journal, pp. 165-198 at 167. See also, Article 17 of the Rome Statute.

5"Rome Statute of the International Criminal Court (2002) Available online at: http://www.icc-cpi.int/nr/rdonlyres/ea9aeff7-5752-4f84-be94-0a655eb30e16/0/rome_statute_english.pdf [accessed 20th February, 2016]. 
\& Stevenson, 2004). Put differently, for a crime to suffice as crime against humanity, such an act must have been done according to a "fixed plan" or a "system". An ad hoc definition of a "Plan" is an intention or a decision about what one is going to do (Soanes \& Stevenson, 2004). It would not be wrong to infer from this exposition that for an act to qualify as crime against humanity, it could be presumed that the perpetrators must have planned the attack systematically or deliberately.

The term "Systematic" was defined by the International Criminal Court for Rwanda as "...thoroughly organised and following a regular pattern on the basis of a common policy involving substantial public or private resources" ${ }^{3}$. From this definition, one could infer why the International Criminal Court for Rwanda opined that the attack should be thoroughly authorised, following a chain of command or a regular pattern (Russell, 2011). The problem now is how can one phantom the policies that would have organized these crimes when they are not made known or kept secret? Sometimes it is often very difficult to discern between public and private resources used in the perpetration of these heinous crimes, particularly when the sources of the resources used are unclear.

Another issue to consider is where the perpetrators kill for fun or kill for what they feel is morally right without State or private sponsors as in the case of Anders Behring Breivik killed eight people on the 22 July 2011, in Regjeringskvartalet in Oslo, by detonating a bomb and then shot dead 69 participants of a Workers' Youth League (AUF) summer camp on the Island of Utøya ${ }^{7}$. Even though the attack could be said to be "systematic" or premeditated, if the ICTR'S definition of “systemic" is something to go by, then Brevick wouldn't be liable because he was the sole financial of the attack and he did not follow any chain of command as he carried out the attacks alone.

Therefore, it can be argued that the word "systematic" should be expunged from the wordings of Article 7. In as much as the crime satisfies the criterion of "widespread" even though not "systematic", it should be regarded as crime against humanity. This would definitely remove the encumbrance placed on the said Article 7.

\section{The Jurisprudential Problem with "Widespread"}

Article 7 of the Rome Statute tends to show that the impact of the said attack must be extensive, or of a very large extent, to qualify as "widespread". According to Article 7 (1):

"... 'crime against humanity' means any of the following acts when committed as part of widespread or systematic attack directed against any civilian population, with knowledge of the attack ...."8

${ }^{6}$ Home Office: “Peace Studies," See also, Prosecutor v. Jean Paul Akayesu (judgement) Case no. ICTR-96-4-T. Trial Chamber 1, 2 September 1998 at 500.

${ }^{7}$ Home Office: “Wikipedia”, (2016) Available online: https://en.wikipedia.org/wiki/Anders_Behring_Breivik [accessed on 28th August 2016].

${ }^{8}$ Rome Statute of the International Criminal Court (2002) Available online at: http://www.icc-cpi.int/nr/rdonlyres/ea9aeff7-5752-4f84-be94-0a655eb30e16/0/rome_statute_english.pdf [accessed, 20th February, 2016]. 
The Pre-Trial Chambers 1 of the International Criminal Court in an attempt to define what could be termed as "widespread", held that the attack need not be a random occurrence but must have been targeted at a perceived group using a variety of means to identify the group". The Court held further that both requirement of "widespread" and "systematic" may exist in one scenario but the existence of either of them is sufficient to establish an offence ${ }^{10}$. Similarly, in the case of Prosecutor v. Akayesu, the Court held that widespread criteria may be defined as "... massive, frequent, large scale action, carried out collectively with considerable seriousness and directed against a multiplicity of victims"11.

Even though the Court tried to interpret "widespread", the problem, however, is that: To what extent is the magnitude of the atrocities that must be committed or the number of people that must be killed, rape or exterminated, etc., to qualify for "massive, frequent and large scale action" or "multiplicity of victims", in order to satisfy the criterion of widespread in crime against humanity under Article 7 of the Rome Statute? Also, where the Court held that the action must be carried out with some "considerable seriousness," how do we determine the seriousness of individuals who are obsessed to kill? As a matter of fact, there are some individuals who will kill without motive but for the fun of it. Will these set of individuals be deemed to have violated the provisions of Article 7 of the Rome Statute?

At this juncture, we shall also consider the provisions of Article 7(2a) which gives a broader interpretation of Article 7(1). It states as follows:

"attack directed against any civilian population" meant a course of conduct involving multiple commission of acts referred to in paragraph 1 against any civilian population, pursuant to or in furtherance of a state or organizational policy to commit such attack.

The problem with this provision is in the interpretation problem of "civilian", "policy" and an "organization" as it relates to crime against humanity.

\section{The Jurisprudential Problem with "Civilian"}

The problem with "civilian" under Article 7 of the Rome Statute is that the Statute did not define who exactly is a civilian under the Statute. The Statute did not make it abundantly clear if it had adopted the definition of a "civilian" under International Humanitarian Law ${ }^{12}$. "Civilians" under International Humanitarian law, "are persons

\footnotetext{
${ }^{9}$ Russell (2011) "The Chapeau of Crime Against Humanity: The Impact of the Rome Statute of the International Criminal Court." 8(1) eyes on the ICC. 25-72.

${ }^{10}$ The Prosecutor v. Francis Kirmin Mutaura, Uhuru Mulgai Kenyatta and Mohammed Hussein Ali (2012) ICC 01/09-2/11-382 (International Criminal Court's case).

${ }^{11}$ Russel “Crime Against Humanity-Understanding the Impact of the Rome Statute of the ICC." Available online on http://works.bepress.com/cgi/viewcontent.cgi?article=1000\&context=cameron_russell. [accessedon $3^{\text {rd } A p r i l ~ 2016] . ~}$

${ }^{12}$ International humanitarian law (also called the law of armed conflicts or the law of war) regulates relations between States, international organisations and other subjects of international law. It is a branch of public international law which consists of rules that, in times of armed conflicts, seek-for humanitarian reasons-to protect persons who are not or are no longer directly participating in the hostilities or fighting, and to restrict the means and methods of warfare. See "IHL: Answers to your Questions", ICRC, Geneva, 2014, p. 4.
} 
who are not members of the armed forces" ${ }^{13}$. In fact, Article 13(2) of Additional Protocol II of $1977^{14}$ forbids the killing of civilians or the making of them objects of attack (Henckaerts, 2005). The Protocol further distinguishes between a civilian and a combatant and. It was agreed upon that one may kill active combatants but not civilians ${ }^{15}$.

If the above is anything to go by, then the gross violation of Article 7 in a widespread or systemic manner may not after all be regarded as crime against humanity if the perpetrators argue in favour of defending themselves against combatants. For instance, the Government of Syria has defended its crackdown on protesters by claiming that they were fighting 'terrorists and armed groups' even though there were series of allegations of crime against humanity levied against the Government including that of the United Nations' Secretary General ${ }^{16}$.

In an attempt to put to rest the definitional crises of who is to be referred to as a "civilian" under the Statute, the International Criminal Tribunal for Rwanda (ICTR) adopted in the case of Rutaganda, Musema, and Seromba's the provisions of Article 3 of the Geneva Convention which defined a "civilian" to mean a person who is not taking part in active hostilities ${ }^{17}$. It is the view of this article that the court has added more injuries to the vagueness of Article 7 because the said Article 3(1) of the Geneva Convention went further in defining a "civilian" to mean... members of armed forces who have laid down their arms and those placed hors de combat by sickness, wounds, detention, or any other cause $e^{18}$. Thus, it is not crime against humanity to kill civilians who possess weapons for the purpose of self-defence or security.

In the Pre-Trial Chambers case of Katanga, Chui and Bemba, the International Criminal Court became silent on this issue. The Court did not clearly state if it accepted or rejected the definition of a civilian to "exclude combatants' hors de combatant, but held that such a person may be counted as a victim"19. The lack of clarity of this nature

\footnotetext{
$\overline{{ }^{13} \text { Customary International Humanitarian Law Rule } 5 .}$

${ }^{14}$ The two Protocols of 1977 are additional to the four Geneva Conventions of August 12, 1949.

${ }^{15}$ Conventions on the Prohibition of the Use, Stockpiling, Production, and Transfer of Anti-personnel Mines and on their Destruction (1997) Available online on: http://www.un.org/Depts/mine/UNDocs/ban_trty.htm [accessed 3rd September, 2016].

${ }^{16}$ UN News Centre (2016). Available on HYPERLINK

http://www.un.org/apps/news/story.asp?NewsID=53181\l. "Vtg0e09cAvI"

http://www.un.org/apps/news/story.asp?NewsID=53181\#.Vtg0e09cAvI [accessed 3rd March 2016]. See also Donnell P., "Syrian Authorities, Opposition Trade Blames in Civilian Deaths" Los Angeles Times of Monday 12 March, 2012. Available on this website:

http://articles.latimes.com/2012/mar/12/world/la-fg-syria-homs-20120313 [accessed 5th March 2016] see also, The United Nations. Available online on http://www.un.org/Depts/mine/UNDocs/ban_trty.htm [accessed 3rdDecember, 2016] also see The Guardian Newspaper (UK) (2012), "Ban ki-Moon Accuses Syrian Regime of Potential Crime against Humanity," Available online:

www.guardian.co.uk/world/2012/feb/16/united-nations-syria-crimes-against-humanity [accessed15th January, 2016]

${ }^{17}$ However, that the four Geneva Conventions of August 12, 1949, remain the cornerstone of the law of war or international humanitarian law. See IHL: Answers to your Questions, op. cit.

${ }^{18}$ Yale Law School, Lilian Goldman Library, "The Avalon Project Documents in Law, History and Diploma$c y$ ”, available online at $\mathrm{http}: / /$ avalon.law.yale.edu/20th_century/geneva03.asp\#art1 $\left[\right.$ accessed $24^{\text {th }}$ January, 2016].

${ }^{19}$ Russel "Crime Against Humanity-Understanding the Impact of the Rome Statute of the ICC." Available online on http://works.bepress.com/cgi/viewcontent.cgi?article=1000\&context=cameron_russell
} 
would put the Court in a difficult place in setting a clear judicial precedent.

"Civilian" under Article 7 should have been restricted expressly to mean "persons who are not members of the military or police force". If this is done, the Statute would have succeeded in giving a clearer interpretation. This would have made someone like the Syrian President, Assad, to be liable for crimes against humanity during the ongoing Syrian civil war with a very clear interpretation of who exactly is a "civilian" under the Rome Statute.

\section{The Jurisprudential Problem with the Requirement of "Organizational"}

It is good to note that there is no particular "legal certainty" ${ }^{20}$ as to what exactly should be defined or regarded as an "organisation", or how many persons would make up such group or organisation. It is not clear what the nature or the scale of the attack. Although the Rome Statute does not have jurisdiction over terrorism, but it is well known that terrorist groups have one of the most organised groups around the globe. It is therefore not clear if their cell or sect would qualify as an "organisation". For instance, United Nations High Commissioner for Human Right and the former President of Ireland, Mary Robinson, was of the view that the September 11, 2001 attack of the United States as a result of its nature and its scale, and to whom it was directed which were civilians should have been held to be crime against humanity ${ }^{21}$. This legal uncertainty clearly has made the exact nature and what exactly is crime against humanity problematic the more.

The Pre-Trial II Chambers, for instance, saw an "organization" as a structure lacking state-like characteristics ${ }^{22}$. If this definition is something to go by, with respect to the Court, the definition contravenes the provision of Article 7(2a). The scholar agrees with the view of justice Hans-Peter Kaul, in its dissenting opinion, in which he was of the view that an organisation should not be seen in that light but as a group which is more state-like in nature.

The Statute should clearly state the number of members of an organisation that would qualify as "an organization" under crime against humanity. In the view of the researcher, an individual should even qualify as an organization; this would go a long way in making individuals who carry out independent attacks liable and also remove the problem of future interpretation.

\section{The "Policy Requirement" Problem}

The problem with "policy" as required under Article 7(2) is what exactly is the said "policy" that would qualify as crime against humanity? According to Article 7(2):

\footnotetext{
${ }^{20}$ Russel op cit.

${ }^{21}$ The American NGO Coalition for International Criminal Court: "Terrorism and the International Criminai Court," available online on

http://webcache.googleusercontent.com/search?q=cache:kWaO7-v4wRYJ:www.amicc.org/docs/terrorism.pdf $+\& \mathrm{~cd}=1 \& \mathrm{hl}=\mathrm{en} \& \mathrm{ct}=\mathrm{clnk} \& \mathrm{gl}=\mathrm{ng}$ [accessed 26th January, 2016].

${ }^{22}$ Rusellop. cit.
} 
"Attack directed against any civilian population" meant a course of conduct involving multiple commission of acts referred to in paragraph 1 against any civilian population, pursuant to or in furtherance of a state or organizational policy to commit such $\operatorname{attack}^{23}$.

According to Article 31 of the Vienna Convention on the Law of Treaties, under the general rule of interpretation, it provides that a treaty must be interpreted in accordance with the ordinary meaning in the light with its object and purposes ${ }^{24}$. If this is adopted, the literal meaning of "policy" is "a course of principle of action adopted or proposed by an organization or individua ${ }^{25}$. In respect to this definition, policy can either be adopted or proposed by an "organization" or an "individual."

It would not be wrong to conclude that one cannot separatean organization or an individual from who can propose or adopt a "policy". It is however not clear if an individual can be deemed to be capable under Article 7 of the Rome Statute of independently formulating a "policy" that would qualify as crime against humanity. This clarification would go a long way in removing the ambiguity created by this Article.

\section{Conclusions}

The emergence of the Statute of Rome and the eventual establishment of the International Criminal Court were a welcomed development in the field of international criminal law and international humanitarian law. They ended the long awaited cry for the adoption of a Statute and a Court with jurisdiction to try the perpetrators of international crimes, of which crimes against humanity is an integral part (Russell, 2011). However, the provision of Article 7 of the Statute, which deals with crime against humanity, has not actually succeeded in the development of the jurisprudence of crime against humanity. As we have seen above, some critical jurisprudential problems of clarity have arisen under Article 7 when it comes to interpretation of the Statute on the offence of crimes against humanity. The hiatus created by this Article 7 is subliminal when States bring perpetrators of crime against humanity to justice or when prosecutors refer them to ICC. Under unclear and imprecise difficulties of interpretations, justice will never be seen to be done. Meanwhile, the International Criminal Court as the last hope of the common man has a burden to deliver justice to those seeking it.

For these reasons, the article concludes by recommending that the wordings of Article 7 of the Rome Statute be re-appraised, in order to illuminate the law and improve the jurisprudence of interpretation of crime against humanity. Since the influx of abuse of human rights and dignity perpetuated by those carrying out crimes against humanity are on the increase, the Court should not compound the weight on it by spending most of its precious time on the interpretation of the Statute so that when those accused of the crimes are brought to the Court, the proceedings can be done faster, with the full force of an apparent interpretation. In this way, the International Criminal Court can

\section{${ }^{23}$ Ibid.}

${ }^{24}$ Article 31 of the Vienna Convention on the Law of Treaties (1969), 1155 U.N.T.S. 331.

${ }^{25}$ Oxford University Press (2016) Available online: https://en.oxforddictionaries.com/definition/policy [accessed 25th February, 2016] 
carve a niche for itself around the globe as a court of justice.

\section{References}

Antonio (2002). The Rome Statute of the International Criminal Court: A Commentary. London: Oxford University Press.

Broomhall, B. (2003). International Justice and the International Criminal Court (1st ed., p. 67). New York: Oxford University Press.

Cassese, A. (2002). The Rome Statute of the International Criminal Court: A Commentary (4th ed., pp. 10-11). New York: Oxford University Press. http://dx.doi.org/10.1093/law/9780198298625.001.0001

Dadrian, V. (1989). Genocide as a Problem of National and International Law: The World War I Armenian Case and Its Contemporary Legal Ramifications. Yale Journal of International Law, 14, 275-295.

Diane, F. (1991). Settling Accounts: The Duty to Prosecute Human Rights Violations of a Prior Regime. Yale Law Journal, 100, 2567-2690.

Ebrucoban, O. (2014). The International Criminal Jurisdiction and the Concept of Sovereignty. European Scientific Journals, 10, 142-155.

Henckaerts, M. (2005). Study on Customary International Humanitarian Law (1st ed., p. 5). New York: Cambridge University Press.

Linda, E. (2010). The Principle of Complementarity and International Criminal Court: The Role of Ne Bis in Idem. Santa Clara Law Journal, 8, 165-198.

Mauro, P., \& Giuseppe, N. (2001). The Rome Statute of the International Criminal Court. A Challenge to Impunity. Burlington: Ashgate.

Otto (1999). Commentary on the Rome Statute of the International Criminal Court (2nd ed.). Novos, Verlagsgesellschaft, Beck/Hart, xix.

Russell, C. (2011). The Chapeau of Crime Against Humanity: The Impact of the Rome Statute of the International Criminal Court. Eyes on the ICC, 8, 25-72.

Soanes, C., \& Stevenson, A. (2004). Concise Oxford English dictionary (11th ed., pp. 1462, 1095). Oxford: Oxford University Press.

The Convention on the Prevention and Punishment of the Crime of Genocide (1948) 78 U.N.T.S. 277.

The Prosecutor v. Jean paul Akayesu (Judgement) Case no. ICTR-96-4-T, TRIAL CHAMBER 1, 2 September, 1998.

The Prosecutor vs Francis Kirmin Mutaura, Uhuru Mulgai Kenyatta and Mohammed Hussein Ali (2012) ICC 01/09-2/11-382. (International Criminal Court's Case).

The Vienna Convention on the Law of Treaties (1969), 1155 U.N.T.S. 331.

Theodorakis, N., \& Farrington, D. (2013). Emerging Challenges for Criminology: Drawing the Margins of Crimes against Humanity. International Journal of Criminology and Sociological Theory, 6, 1150-1160. 


\section{Online Materials}

http://avalon.law.yale.edu/20th_century/geneva03.asp\#art1

http://works.bepress.com/cgi/viewcontent.cgi?article=1000\&context=cameron_russell http://www.icc-cpi.int/nr/rdonlyres/ea9aeff7-5752-4f84-be94-0a655eb30e16/0/rome_st atute_english.pdf

https://irpond.wordpress.com/?s=theeuropeans-+have-got-it-right-iustice-does-not-co me-in-a-helicopter

Wikipedia. Available on: https://en.wikipedia.org/wiki/Anders_Behring_Breivik

https://en.oxforddictionaries.com/definition/policy http://www.un.org/apps/news/story.asp?NewsID=53181\#.Vtg0e09cAvI

http://articles.latimes.com/2012/mar/12/world/la-fg-syria-homs-20120313

http://www.un.org/Depts/mine/UNDocs/ban_trty.htm

www.guardian.co.uk/world/2012/feb/16/united-nations-syria-crimes-against-humanity http://webcache.googleusercontent.com/search?q=cache:kWaO7-v4wRYJ:www.amicc.o $\underline{\mathrm{rg} / \text { docs/terrorism.pdf }+\& \mathrm{~cd}=1 \& \mathrm{hl}=\mathrm{en} \& \mathrm{ct}=\mathrm{clnk} \& \mathrm{gl}=\mathrm{ng}}$

Submit or recommend next manuscript to SCIRP and we will provide best service for you:

Accepting pre-submission inquiries through Email, Facebook, LinkedIn, Twitter, etc. A wide selection of journals (inclusive of 9 subjects, more than 200 journals)

Providing 24-hour high-quality service

User-friendly online submission system

Fair and swift peer-review system

Efficient typesetting and proofreading procedure

Display of the result of downloads and visits, as well as the number of cited articles Maximum dissemination of your research work

Submit your manuscript at: http://papersubmission.scirp.org/

Or contact blr@scirp.org 